\title{
The c.3140-26A>G Variant of the CFTR Gene in Homozygous State Causes Mild Cystic Fibrosis - Overview of Longitudinal Clinical Data of the Patient Managed in our CF Center and Review of the Literature
}

\author{
Ana Kotnik Pirš, ${ }^{1,2,{ }^{*}}$ Uroš Krivec $^{1}$ and Katarina Trebušak Podkrajšek ${ }^{3,4}$ \\ ${ }^{1}$ Unit for Pulmonary Diseases, University Children's Hospital, University Medical Centre Ljubljana, \\ Bohoričeva 20, 1000 Ljubljana, Slovenia \\ ${ }^{2}$ Department for Pediatrics, Faculty of Medicine, University of Ljubljana, Bohoričeva 20, 1000 Ljubljana, Slovenia \\ ${ }^{3}$ Institute of Biochemistry, Faculty of Medicine, University of Ljubljana, Vrazov trg 2, 1000 Ljubljana, Slovenia \\ ${ }^{4}$ Clinical Institute for Special Laboratory Diagnostics, University Children's Hospital, University Medical Centre Ljubljana, \\ Vrazov trg 1, 1000 Ljubljana, Slovenia \\ *Corresponding author: E-mail: ana.kotnikpirs@kclj.si \\ Tel.: +3861522 9257; Fax: + 38615224073.
}

Received: 11-40-2019

\begin{abstract}
There are over 70.000 patients with cystic fibrosis $(\mathrm{CF})$ in the world and numerous sequence variations in the CFTR gene have been reported but the clinical significance of all of them is still not known. There are currently 195 patients with the c.3140-26A>G (legacy name 3272-26A >G) variant in the CFTR gene listed in the European Cystic Fibrosis Society Patient Registry (ECFSPR) and only 4 are homozygous. We present longitudinal clinical data of one of these patients who is managed in our CF Center at the University Children's Hospital in Ljubljana and compare it with the patient data from the ECFSPR and the CFTR2 database in which additional 3 homozygous patients are described.

Moreover, the effect of the detected variant in the described patient was evaluated on the RNA level in nasal epithelial cells. The variant was shown to result in aberrant splicing introducing a frameshift and a premature termination codon while normal transcript was not detected. Alternative spliced mutant transcripts in other tissues or the presence of spliceosome-mediated RNA trans-splicing could explain the mild clinical presentation of patients with this variant in homozygous state.
\end{abstract}

\section{Introduction}

\section{1. Cystic Fibrosis}

Cystic fibrosis (CF) is one of the most common inherited diseases in Caucasians. The incidence of the disease differs between populations with the highest incidence in Ireland 1:1.800 and the lowest in Finland with 1:20.000. ${ }^{1}$ The incidence of CF in Slovenia is $1: 4.500 .{ }^{2} \mathrm{CF}$ affects many organs. The lungs, gastrointestinal system, pancreas, liver, nose and sweat glands are most commonly involved. In 1989 the CFTR gene was discovered and variants of this gene were shown to be causative of CF. ${ }^{3}$ In 2016 De Boeck and Amaral ${ }^{4}$ updated the 1995 Zielinski and Tsui $^{5}$ classification of CFTR variants from 5 classes to 7 according to the mechanism by which they disrupt the synthesis, trafficking and function of the CFTR protein.

$\mathrm{CF}$ is diagnosed on the basis of clinical presentation, sweat testing and genetic confirmation. ${ }^{6}$ To date there are over 44.000 sequence variants listed in the Ensembl genome browser 98 (https://www.ensembl.org/index.html; accessed in October 2019) in the CFTR gene, but not all of them are disease causing. In October 2019, more than $1800 \mathrm{CF}$ causing variants located in the coding region, splice sites and the regulatory regions of the CFTR gene have been reported in the professional version of the $\mathrm{Hu}$ man Gene Mutation Database. ${ }^{7}$

Incredible progress has been made in the past 10 years in the treatment of CF. Regular therapy that improves 
the symptoms which are a consequence of CFTR dysfunction has been a cornerstone of CF therapy since the implementation of pancreatic enzyme replacement therapy (PERT) shortly after the first description of CF by Dorothy Hansine Andersen in $1938 .{ }^{8}$ New medications that influence the CFTR directly have been developed and implemented into regular therapy in 2014. New drugs named CFTR modulators work in two ways - as potentiators they enhance the function of the CFTR on the apical cell membrane in patients with milder CFTR variants in which the number or the function of the CFTR is affected. The second class are CFTR correctors - they influence the translation, folding and transport of the CFTR to the apical membrane in patients with severe variants in which there is only a small number of dysfunctional CFTR on the apical membrane or none at all. Potentiators (ivacaftor) are beneficial in patients with splicing variants as are the patients presented in our review, while a combination of potentiators and correctors, such as the recently approved triple combination of elexacaftor/ivacaftor/tezacaftor, is needed in patients with the classic severe CFTR variants such as the common p.Phe508del variant. ${ }^{9}$

Even with all the progress that has been made, most leading authorities in the field of CF believe that only close follow-up of patients can show the effect of a particular variant on a particular patient. It is widely accepted that two patients with the same disease causing variant can have an entirely different clinical progress of CF. ${ }^{10,11}$

\section{2. The c.3140-26A >G CFTR Variant}

According to the CFTR1 and CFTR2 mutation databases and the so far published literature, the c.3140-26A $>\mathrm{G}$ variant (legacy name 3272-26A>G) is considered to be a mild variant of the CFTR gene. ${ }^{12,13}$ Based on the combination of clinical and functional evaluation it is listed as a disease causing variant. According to CFTR1 and CFTR2, this variant does not need functional testing. ${ }^{12-14}$ Most of the patients in the European Cystic Fibrosis Society Patient Registry (ECFSPR) and the CFTR2 database are compound heterozygotes, only 7 patients altogether are homozygotes. Therefore, it is believed that the variant is clinically important especially when in combination with another disease causing variant. Patients with this variant are likely to be pancreatic sufficient. ${ }^{13}$ According to the published literature patients have mild signs of pulmonary disease. Some authors report that nasal polyps and chronic rhinosinusitis are more common. ${ }^{15-17}$ After a thorough search through the National center for biotechnology information (NCBI) databases on this variant up to October 2019 no comprehensive clinical reports on homozygous patients with this variant have been published so far. We describe 12 year longitudinal clinical data on a homozygous patient with this variant managed in our CF Center.

\section{Methods}

All existing medical records were analyzed and clinical examinations were performed as recommended by the ECFS DNWG. ${ }^{6}$ Evaluations were performed at the University Children's Hospital, University Medical Centre Ljubljana, Slovenia, where written informed consent was obtained from the parents prior to the study and Declaration of Helsinki protocols were followed.

Genomic DNA was isolated from blood leucocytes using the FlexiGene DNA Kit 250 (Qiagen, Germany) according to an established laboratory protocol. Initial mutation screening with Oligonucleotide Ligation Cystic Fibrosis Assay (Abbott, Germany) did not detect any of the 32 analyzed variants. Therefore, the CFTR coding region together with exon-intron boundaries were PCR amplified using in-house designed primers (Table 1) and sequenced with the BigDye Terminator v.3.1 Cycle Sequencing Kit and the 3500 Genetic Analyzer capillary electrophoresis system (Life Technologies, USA). Identified sequence variants were confirmed by sequencing of the additional independent PCR amplicon.

To demonstrate the effect of the identified c.3140$26 \mathrm{~A}>\mathrm{G}$ variant in vivo, total RNA of the patient, her mother and two unrelated healthy control subjects was purified from nasal epithelial cells using QIAzol Lysis Reagent and

Table 1. Primers used for the sequencing of the CFTR gene coding region and CDNA.

\begin{tabular}{lllll}
\hline Exon nr. & Exon nr. & sequence 5'-3' (legacy) & Amplicon length (bp) & Cycling conditions \\
\hline 1 & 1 & $\begin{array}{l}\text { cagcactcggctttaacct } \\
\text { catacacacgcctcctctt }\end{array}$ & 336 & $\begin{array}{l}\text { Annealing } \\
\text { temperature:59 }{ }^{\circ} \mathrm{C} ;\end{array}$ \\
\hline 2 & 2 & $\begin{array}{l}\text { ttccatatgccagaaagttga } \\
\text { gccaccatacttggctccta }\end{array}$ & 328 \\
\hline 3 & 3 & $\begin{array}{l}\text { cettggatatacttgtgtgaatcaa } \\
\text { ttggagttggattcatcctt }\end{array}$ & 332 \\
\hline 4 & $\begin{array}{l}\text { aaacttgtctccactgttgct } \\
\text { ttaatttcagcatttatccttacttg }\end{array}$ & 543 \\
\hline
\end{tabular}




\begin{tabular}{|c|c|c|c|c|}
\hline Exon nr. & Exon nr. & sequence 5'-3' (legacy) & Amplicon length (bp) & Cycling conditions \\
\hline 5 & 5 & $\begin{array}{l}\text { gcctagatgctgggaaataaaac } \\
\text { ttactattatctgacccaggaaaactc }\end{array}$ & 411 & \\
\hline 6 & $6 a$ & $\begin{array}{l}\text { ttgttagtttctaggggtggaaga } \\
\text { gcagtcctggttttactaaagtgg }\end{array}$ & 305 & \\
\hline 7 & $6 \mathrm{~b}$ & $\begin{array}{l}\text { gggatagagatagcatatggaatgag } \\
\text { acaaacatcaaatatgaggtggaag }\end{array}$ & 449 & \\
\hline 8 & 7 & $\begin{array}{l}\text { catgctcagatcttccattcc } \\
\text { ttttctatcttttcgcacattttt }\end{array}$ & 431 & \\
\hline 9 & 8 & $\begin{array}{l}\text { cattagtgggtaattcagggttg } \\
\text { ggatgaaatccatattcacaaaga }\end{array}$ & 497 & \\
\hline 10 & 9 & $\begin{array}{l}\text { ggccatgtgcttttcaaact } \\
\text { ctccaaaaataccttccagcac }\end{array}$ & 389 & \\
\hline 11 & 10 & $\begin{array}{l}\text { caagtgaatcctgagcgtga } \\
\text { tccattcacagtagcttacccata }\end{array}$ & 387 & \\
\hline 12 & 11 & $\begin{array}{l}\text { tgaatttgtaaaatggacctatgga } \\
\text { caattccagaaacagaatataaagca }\end{array}$ & 533 & \\
\hline 13 & 12 & $\begin{array}{l}\text { gtaatgcatgtagtgaactgtttaagg } \\
\text { tttagcatgaggcggtgag }\end{array}$ & 398 & \\
\hline 16 & $14 \mathrm{~b}$ & $\begin{array}{l}\text { gcatgggaggaataggtgaa } \\
\text { gcctgtggaggagctagga }\end{array}$ & 305 & \\
\hline 17 & 15 & $\begin{array}{l}\text { ccatttacatgtattggaaattcag } \\
\text { acaaaaccacaggccctatt }\end{array}$ & 398 & \\
\hline 18 & 16 & $\begin{array}{l}\text { aatgcgtctactgtgatccaaac } \\
\text { gacaggacttcaaccctcaatc }\end{array}$ & 288 & \\
\hline 19 & $17 \mathrm{a}$ & $\begin{array}{l}\text { caatgtgaaaatgtttactcaccaac } \\
\text { ttgggaacccagagaaacct }\end{array}$ & 542 & \\
\hline 20 & $17 \mathrm{~b}$ & $\begin{array}{l}\text { caaagaatggcaccagtgtg } \\
\text { aaacaatggaaattcaaagaaatca }\end{array}$ & 387 & \\
\hline 21 & 18 & $\begin{array}{l}\text { tgatatgtgccctaggagaagtg } \\
\text { cagtgaccctcaatttatctgtaatg }\end{array}$ & 329 & \\
\hline 22 & 19 & $\begin{array}{l}\text { aaagcccgacaaataaccaa } \\
\text { tcaggctactgggattcacttac }\end{array}$ & 443 & \\
\hline 23 & 20 & $\begin{array}{l}\text { ttccactggtgacaggataaaa } \\
\text { aaaaagacagcaatgcataacaaa }\end{array}$ & 399 & \\
\hline 24 & 21 & $\begin{array}{l}\text { tgatggtaagtacatgggtgtttc } \\
\text { aaaatcatttcagttaggggtaggt }\end{array}$ & 411 & \\
\hline 27 & 24 & $\begin{array}{l}\text { ccagtttctgtccetgctct } \\
\text { gtgtcctcaattcccettacc }\end{array}$ & 439 & \\
\hline 14 & 13 & $\begin{array}{l}\text { gagagaccccgaggataaatg } \\
\text { tgcattctgtggggtgaaa }\end{array}$ & 1066 & \multirow{3}{*}{$\begin{array}{l}\text { Annealing } \\
\text { temperature: } 59^{\circ} \mathrm{C} \text {; } \\
\text { elongation } 1^{\prime}\end{array}$} \\
\hline 15 & $14 \mathrm{a}$ & $\begin{array}{l}\text { accacaatggtggcatgaa } \\
\text { ctccccactcagtctcctaaaa }\end{array}$ & 791 & \\
\hline 25,26 & 22,23 & $\begin{array}{l}\text { gaatgtcaactgcttgagtgtttt } \\
\text { tgagtaaagctggatggctgt }\end{array}$ & 1081 & \\
\hline $\begin{array}{l}\text { cDNA: } 18 \\
19,20\end{array}$ & $\begin{array}{l}\text { cDNA: } 16 \\
17 a, 17 b\end{array}$ & $\begin{array}{l}\text { ccaaacctcacagcaactca } \\
\text { tggctaaagtcaggataataccaa }\end{array}$ & 308 & $\begin{array}{l}\text { Annealing } \\
\text { temperature: } 58^{\circ} \mathrm{C}\end{array}$ \\
\hline
\end{tabular}


Qiagen RNAEasyMini Kit (Qiagen, Germany) according to the manufacturer's instructions. Reverse transcription of the total RNA was performed with random hexamers (Applied Biosystem, Foster City, CA, USA) and SuperScript II Reverse Transcriptase (Invitrogen, USA). CFTR cDNA was amplified with primer pair aligning exon 16 (forward primer) and exon 17B (reverse primer) (Table 1) and sequenced. Additionally, control amplification of the TP53 gene was performed.

\section{Results}

\section{1. Clinical Characteristics}

In 2007 a 12-year-old girl with unrelated parents and no family history of chronic disease was referred to our pediatric pulmonologist clinic because of persistent dry cough. The girl was born at term as the second child after a second uneventful pregnancy and birth. She was gaining weight and height well. At the age of 4 years she had a viral pneumonia without any complications. From the age of 9 she had nasal discharge, tearing and sneezing especially in the spring. From the age of 11 she was coughing almost persistently particularly when in contact with dust mite, after exertion and while laughing. She had no history of diarrhea, bulky, fatty feces, stomach discomfort or distention.

At the time of her first visit, the girl had a healthy appearance. Her weight, height and body mass index were on the $75^{\text {th }}, 99^{\text {th }}$ and $34^{\text {th }}$ percentile for age and gender respectively. The clinical examination was normal beside a partially blocked nose. On spirometry the forced vital capacity (FVC) was $80 \%$ of predicted values for age, height and gender, the forced expiratory volume in one second (FEV1) $72 \%$ and the Tiffenau index 89. Asthma was excluded with a negative Metacholine Challenge Test. She had normal levels of exhaled and nasal nitric oxide (FeNO). Allergies were excluded with skin prick testing and blood IgE evaluation and her chest X-ray was normal.

She returned to our outpatient clinic after 3 years because of persistent and worsening cough. She had no other signs or symptoms of CF. Sweat testing was performed using the Gibson-Cooke method. The sweat chloride levels were elevated on two separate examinations: 56 and 57.7 $\mathrm{mmol} / \mathrm{l}$ - the high end of intermediate levels. In concordance with the European recommendations for molecular genetic diagnosis of CF and CFTR-related disorders ${ }^{17}$ molecular diagnostic testing was issued confirming the diagnosis of CF with identification of the c.3140-26A $>\mathrm{G}$ variant in homozygous state.

For the last 12 years, since the diagnosis was confirmed, the patient has been managed in our center for children and adolescents with CF according to the standards of care. ${ }^{18}$ She is pancreatic sufficient with normal fecal elastase levels, has normal liver function tests and abdominal ultrasound, normal levels of A, D, E, K vita- mins without supplementation, glucose metabolism and bone density. She has chronic rhinitis, but no nasal polyps. Her chest $\mathrm{x}$-ray is normal therefore a chest CT has not been done yet. Her FEV1 is currently $70 \%$ predicted, with a yearly decline of $0.6 \%$ despite regular adherence to inhalatory hypertonic saline therapy and respiratory physiotherapy. Pseudomonas aeruginosa $(\mathrm{Pa})$ has never been isolated from her sputum and her serum anti-Pseudomonas aeruginosa IgG antibodies are low.

\section{2. Genetic Analyses}

Sequencing in the patient revealed the c.314026A $>$ G CFTR variant (reference sequence NM_000492.3) in homozygous state; no additional disease causing variants were identified in the coding region or in the exon/ intron boundaries. Parents were shown to be carriers of the same variant in heterozygous state. CFTR mRNA analysis showed an aberrant splicing pattern with $25 \mathrm{nu}$ cleotides inserted between exons 17A in 17B in the patient but not in her mother nor in healthy control subjects. The 25-nucleotide insertion was matching the last 25 nucleotides of intron 17a (namely TGTTTTCTATGGAAATATTTCACAG) as previously reported. ${ }^{15}$

\section{3. Comparison of Clinical Data of Patients with the c.3140-26A $>$ G CFTR Variant Listed in the ECFSPR and the CFTR2 Database and Our Patient}

After the c.3140-26A $>\mathrm{G}$ variant was confirmed in our patient, clinical data on patients with this variant was requested from the ECFSPR according to standard regulations. There are 195 patients with the c.3140-26A>G mutation currently listed in the ECFSPR. 191 (97.95\%) are heterozygous and $4(2.05 \%)$ homozygous for this variant. At the last data review, all 4 ECFSPR patients were alive. 2 were younger and 2 older than 18 years of age. Their mean age was 20 years, the youngest 3.3 and oldest 34.3 years old. Their mean age at diagnosis was 6 years, the earliest at 3 months and the latest at almost 13 years of age. 2 were diagnosed before the first year of life, none before the first month.

Their lung function described as mean percent of predicted FEV1 was $77.23 \%$ for the patient younger than 18 years and $89.77 \%$ for the 2 patients older than 18 years. The lung function of the 3 year old could not be measured yet by standard spirometry.

Patients over 18 years of age had a mean BMI of $26.22 \mathrm{~kg} / \mathrm{m} 2$ and the BMI expressed with the mean Z score for the two patients under 18 was -0.18 , with a minimum of -1.13 and maximum of 0.76 .

Only one patient needed pancreatic enzyme replacement therapy, the other 3 were pancreatic sufficient. 1 patient was chronically colonized with $S$. aureus and proba- 
Table 2. Comparison of clinical data of patients with the c.3140-26A >G CFTR variant in homozygous state listed in the ECFSPR with the data of our patient.

\begin{tabular}{|c|c|c|c|c|}
\hline \multirow[t]{2}{*}{ Clinical variable } & \multicolumn{3}{|c|}{ ECFSPR patients (Total number: 4) } & \multirow[t]{2}{*}{ Our patient } \\
\hline & mean & minimum & maximum & \\
\hline Age (years) & 20 & 3.3 & 34.4 & 24 \\
\hline Age at diagnosis (years) & 6 & 0.25 & 12.91 & 16 \\
\hline FEV1 (percent predicted) $<18$ years & 77.23 & 77.23 & 77.23 & l \\
\hline FEV1 (percent predicted) $>18$ years & 89.77 & 85.25 & 94.3 & 88 \\
\hline BMI $(\mathrm{Z}$ score $)<18$ years & -0.18 & -1.13 & 0.76 & \\
\hline \multirow[t]{2}{*}{ BMI $(\mathrm{kg} / \mathrm{m} 2)>18$ years } & 26.22 & 22.77 & 29.67 & 20 \\
\hline & no & yes & missing data & \\
\hline Use of pancreatic enzymes & 3 & 1 & 0 & no \\
\hline Chronic Pseudomonas aeruginosa & 3 & 0 & 1 & no \\
\hline Chronic Staphylococcus aureus & 3 & 1 & 3 & yes \\
\hline
\end{tabular}

Table 3. Clinical features of the c.3140-26A $>$ G homozygous patients as listed in the CFTR2 mutation database, compared to all listed CF patients with 2 disease causing mutations and to our patient.

Clinical Feature

$$
\begin{gathered}
\text { Average of all patients } \\
\text { homozygous for c.3140-26A }>\mathrm{G}
\end{gathered}
$$

Our patient

90

$<10$ years: insufficient data

10-20 years: insufficient data

$>20$ years: insufficient data

(FEV1\% predicted)

Pancreatic status

$33 \%$ (2 patients) insufficient

$33 \%$ (2 patients)

16

57

96

$<10$ years: $63-124 \%$

10-20 years: $42-118 \%$

$>20$ years: $25-104 \%$

Pseudomonas aeruginosa

chronic colonization

Average age in years

$70 \%$

$85 \%$ (66.394 patients) insufficient

$55 \%$ (34.460 patients)

chronically colonized

20 bly none with $P$. aeruginosa, but the information on $\mathrm{Pa}$ is missing for one patient. The clinical data are summarized in Table 2.

Clinical features of homozygous patients with the c.3140-26A $>$ G variant were compared to all the other CF patients with $2 \mathrm{CF}$ causing variants listed in the CFTR2 mutation database and to the here reported patient. The data are presented in Table 3.

\section{Discussion with Review of the Published Literature}

A review of the literature in search for the variants characteristics in terms of disease severity was done. A PubMed search using keywords 3272-26A $>$ G or c.3140$26 \mathrm{~A}>\mathrm{G}$ and cystic fibrosis yielded 6 articles. References of relevant articles were analyzed and further 7 articles that mention the mutation were identified. The found references in chronological order are shown in Table 4.

To our knowledge, this is the first longitudinal clinical report on a patient with this variant in homozygous state. According to the so far published literature, c.3140$26 \mathrm{~A}>\mathrm{G}$ is a rare variant so far detected mostly in compound heterozygosity with other disease causing variants. Patients usually have mild disease even when this mutation is paired with a severe disease causing variant. The patients are mostly pancreatic sufficient, have good lung function are on average older and diagnosed at an older age than patients with classic CF variants, but have elevated sweat chloride levels and a higher incidence of nasal polyps. ${ }^{15-17,20-23}$

The largest number of patients with c.3140-26A>G in heterozygous state was presented in a European study by Amaral et al in 2001. ${ }^{14}$ The study included 60 patients from 6 European countries: France, Spain, Greece, Germany, Portugal and Belgium. The mean age of the patients at the time of the study was 20.5 (SD 17.5) years. 44 of the patients had the c.3140-6A>G and the p. Phe508del (c.1521_1523delCTT) combination of disease causing alleles and 16 had c.3140-26A>G in combination with another CF causing variant. Their mean age at diagnosis was 8 (SD 20) years, sweat test chlorides 99.5 (SD 24.7) mEq/1 and FEV1 87 (SD 47) \% predicted. 19 had nasal polyposis 
Table 4. Clinical characteristics of the in the published literature found reports of patients with the c.3140-26A $>\mathrm{G}$ mutation and chronological characterization of the variant. ${ }^{14-16,20-23}$

\begin{tabular}{|c|c|c|c|c|c|c|c|c|c|}
\hline $\begin{array}{l}\text { First author, } \\
\text { year of } \\
\text { publication }\end{array}$ & $\begin{array}{c}\text { Number } \\
\text { of patients } \\
\text { with } \\
3140-26 \mathrm{~A}>\mathrm{G}\end{array}$ & $\begin{array}{c}\text { Genotype: } \\
\text { c.3140-26A }>\mathrm{G} \\
\text { in combination } \\
\text { with }\end{array}$ & Mean age & $\begin{array}{l}\text { Mean age } \\
\text { at } \\
\text { diagnosis }\end{array}$ & $\begin{array}{l}\text { Phen } \\
\text { Mean sweat } \\
\text { chloride } \\
\text { test }\end{array}$ & $\begin{array}{l}\text { notype } \\
\text { Pancreatic } \\
\text { function }\end{array}$ & $\begin{array}{l}\text { Nasal } \\
\text { polyps }\end{array}$ & $\begin{array}{l}\text { Mean } \\
\text { FEV1 }\end{array}$ & $\begin{array}{l}\text { Variant } \\
\text { chara- } \\
\text { cterization }\end{array}$ \\
\hline $\begin{array}{l}\text { Fanen et al, } \\
1992^{23}\end{array}$ & 1 & p.W846X & No data & No data & No data & Sufficient & No data & $\begin{array}{l}\text { Mild } \\
\text { pulmonary } \\
\text { disease }\end{array}$ & \\
\hline $\begin{array}{l}\text { Kanavakis et al, } \\
1995^{16}\end{array}$ & 1, & $\begin{array}{l}\text { 2: p.Phe508del } \\
\text { 1: unknown }\end{array}$ & $\begin{array}{l}11 \text { years } \\
(\mathrm{SD} 7)\end{array}$ & $\begin{array}{l}9.5 \text { years } \\
(\text { SD } 5)\end{array}$ & $\begin{array}{c}105 \mathrm{mEq} / 1 \\
(\mathrm{SD} 7.6)\end{array}$ & $\begin{array}{c}\text { All } \\
\text { pancreatic } \\
\text { sufficient }\end{array}$ & $2 / 3$ & $\begin{array}{c}108 \% \\
(\mathrm{SD} 22.6)\end{array}$ & $\begin{array}{l}\text { Proposition } \\
\text { of the } \\
\text { splicing defect. }\end{array}$ \\
\hline $\begin{array}{l}\text { Beck et al } \\
1999^{15}\end{array}$ & 5 & $\begin{array}{c}\text { 5: } \\
\text { p. Phe508del }\end{array}$ & $\begin{array}{l}18 \text { years } \\
(\mathrm{SD} 10.4)\end{array}$ & $\begin{array}{c}9 \text { years } \\
\text { (SD 13.9) }\end{array}$ & $\begin{array}{c}103 \mathrm{mEq} / 1 \\
(\mathrm{SD} 7.3)\end{array}$ & $\begin{array}{l}4 / 5 \text { sufficient, } \\
1 / 4 \text { mild } \\
\text { insufficiency }\end{array}$ & $4 / 5$ & $\begin{array}{c}68 \% \\
(\mathrm{SD} 24.5)\end{array}$ & $\begin{array}{c}\text { mRNA } \\
\text { confirmation } \\
\text { of the splicing } \\
\text { defect. Mutated } \\
\text { protein } \\
\text { detected on } \\
\text { the epithelial } \\
\text { cell membrane. }\end{array}$ \\
\hline $\begin{array}{l}\text { Amaral et al, } \\
2001\end{array}$ & 60 & $\begin{array}{c}\text { 44: } \mathrm{p} . \\
\text { Phe508del } \\
\text { 16: other } \\
\text { disease } \\
\text { causing }\end{array}$ & $\begin{array}{l}20,5 \text { years } \\
(\text { SD 17.5) }\end{array}$ & $\begin{array}{l}8 \text { years } \\
(\text { SD 20) }\end{array}$ & $\begin{array}{c}99,5 \mathrm{mEq} / 1 \\
(\mathrm{SD} 47)\end{array}$ & $\begin{array}{l}39 \text { sufficient, } \\
16 \text { insufficient }\end{array}$ & $19 / 60$ & $\begin{array}{c}87 \% \\
\text { (SD 47) }\end{array}$ & $\begin{array}{l}\text { Additional } \\
\text { report } \\
\text { of the } \\
\text { mutation. }\end{array}$ \\
\hline $\begin{array}{l}\text { Feldmann } \\
\text { et al, } 2003^{20}\end{array}$ & 2 & $\begin{array}{c}\text { 2: p. } \\
\text { Phe508del }\end{array}$ & $\begin{array}{l}27 \text { years } \\
(\text { SD } 10)\end{array}$ & No data & $\begin{array}{c}62.5 \mathrm{mEq} / 1 \\
(\mathrm{SD} 2)\end{array}$ & No data & No data & No data & $\begin{array}{l}\text { Additional } \\
\text { report of } \\
\text { the mutation. }\end{array}$ \\
\hline $\begin{array}{l}\text { Storm et al, } \\
2007^{21}\end{array}$ & 11 & $\begin{array}{c}\text { 10: p. } \\
\text { Phe508del } \\
1: \text { c.1717-1G>A }\end{array}$ & Clinic & al phenotyp & s milder than & n p. Phe508del & homozyg & gotes & $\begin{array}{c}\text { Additional } \\
\text { report } \\
\text { of the mutation. }\end{array}$ \\
\hline $\begin{array}{l}\text { Jung et al, } \\
201122\end{array}$ & 1 & 1: p.Phe508del & & & No data & & & & $\begin{array}{l}\text { Additional } \\
\text { report of the }\end{array}$ \\
\hline
\end{tabular}

and $18 \mathrm{~Pa}$ colonization. ${ }^{14}$ The other authors reported patients from individual countries or centers and therefore had lower numbers of described patients, all patients were heterozygotes for the c.3140-26A>G variant.

There are two ways to assess the severity of a mutation - on the basis of a patient's clinical status and on a molecular basis. The first is the most reliable but requires long term follow-up. The second can be used as a prediction tool for an approximate evaluation of the probable clinical findings to come. Based on the found data in the literature and the clinical status of our patient we were interested if there is a difference in mutated mRNA translation between hetero and homozygotes for the c.3140$26 \mathrm{~A}>\mathrm{G}$ mutation compared to healthy controls.

On the molecular level, the effect of a gene variant can be studied by observing its influence on RNA translation and protein synthesis. Splicing is a process in which a premature mRNA transcript is formed into mature mRNA. In this process introns are removed and exons which are the coding nucleotide sections within a gene are joined together into mature mRNA which is then translated into a protein. ${ }^{24}$ Errors can occur in splicing, as in all processes. There are presumed to be three classes of variants that effect splicing: variants of a splice site that cause loss of function of that site, variants that cause a disruption of the reading frame and displacement of a splice site that causes shorter or longer exons to be formed. ${ }^{24}$ The HGMD professional 2019.3 currently reports more than 240 different intronic disease causing variants in the CFTR gene. 6 of them are located in the $3^{\prime}$ splice site of intron $17 \mathrm{~A}$, among them 4 including the here reported c.3140-26A $>\mathrm{G}$ in a polypyrimidine tract located between the branch site and the basic acceptor splice site. ${ }^{7}$ The c.3140-26A $>$ G CFTR variant was first described by Fanen et al in 1992 and was suspected to be a variant that effects mRNA splicing. ${ }^{23}$ Additional reports followed in 1995 by Kanavakis et al and in 1999 by Beck et al where aberrant splicing was demonstrated on the mRNA level. ${ }^{16,15}$ The c.3140-26A $>\mathrm{G}$ variant 
results in an insertion of 25 nucleotides of intron 17a of the CFTR gene as confirmed in our patient and causes a frameshift and a premature stop codon in exon $17 \mathrm{~b} .{ }^{15}$ The same insertion in mRNA was present in here reported patient with, They proposed that some of the alternative transcript reaches the cell membrane as a modified CFTR protein. Because of the location of the insertion the alternative protein retains the wild-type CFTR sequence until amino acid residue 1046 which could enable it to have some single chloride conductance remaining. It was proposed that the 36 amino acid extension caused by the insertion can have three different effects on CFTR folding, trafficking and function: a change in stability, missed interaction with PDZ-domain proteins with a probable influence on CFTR stability, chloride conductance regulation and its localization or that the protein would not fold correctly. ${ }^{16}$

In 2001 Amaral et al reported that the alternative acceptor splicing site in intron $17 \mathrm{a}$ competes with normal CFTR mRNA. ${ }^{14}$ Therefore, the remaining normal mRNA is normally processed and leads to some remaining normal protein at the cell membrane. It was postulated that the remaining normal CFTR mRNA still existing in patients with the c.3140-26A $>\mathrm{G}$ variant even when paired with a severe disease causing mutation lessens the severity of $\mathrm{CF}$ disease. It was hypothesized that the c.3140-26A $>\mathrm{G}$ variation on both alleles would avoid CF totally. ${ }^{15}$ This was not confirmed in our study, since the homozygous patient had only mutated splicing pattern present in nasal epithelial cells and normal transcript was not detected. Furthermore, in the analysed heterozygous mother, only normal splicing was present, probably due to preferential transcription of the normal allele. Of course, CFTR expression is tissue specific and the splicing pattern was analysed in nasal epithelial cells, where CFTR gene is known to be expressed in lower levels. ${ }^{25,26} \mathrm{~A}$ mild disease presentation in patients carrying nonsense mutations was previously explained by the presence of alternative spliced mutant transcripts. ${ }^{26}$ This could also be the case in the c.3140-26A>G variant, since we have studied only a selected part of the mRNA transcript in nasal epithelial cells. The other possibility is a presence of spliceosome-mediated RNA trans-splicing already proven to functionally correct endogenous CFTR mutant protein. ${ }^{28}$

\section{Conclusions}

Incredible progress has been made in the past 5 years in the treatment of CF. New gene variant specific medication with CFTR modulators has improved the life and outcome of patients with specific gene defects. Currently numerous CFTR variants are known, but the clinical significance of most of them remains trivial. Case reports on patients with rare CFTR variants are therefore beneficial for the prediction of the clinical course of the disease in other patients with the same variant. 12 year longitudinal data on a CF patient with the c.3140-26A $>$ G variant in homozygous state that is presented in this report adds new knowledge. In our study, aberrant splicing of the mRNA due to the c.3140-26A $>\mathrm{G}$ variant was shown, probably resulting in the mild clinical presentation of the disease. Only speculations can be made on the future quality of life of our patient, but based on the current data we might predict a good outcome especially with the implementation of new variant specific therapy into everyday patient care.

\section{Acknowledgements}

We would like to thank the people with CF and their families for consenting to their data being included in the European Cystic Fibrosis Society Patient Registry, the ECFSPR for providing access to patient data and the individual country representatives for allowing the use of data for publication (www.ecfs.eu/projects/ecfs-patient-registry/steering-committee).

\section{References}

1. P. M. Farrell, B. J. Rosenstein, T. B. White, F. J. Accurso, C. Castellani, G. R. Cutting, et al, The Journal of Pediatrics. 2008, 2: S4-S14. DOI:10.1016/j.jpeds.2008.05.005

2. A. Kotnik Pirs, M. Praprotnik, K. Trebusak Podkrajsek, K. Seme, M. Aldeco, D. Lepej, J. Brecelj, N. Bratanic, U. Krivec, Slov. Pediatr. 2014, 21: 164-171.

3. B. Kerem, J. M. Rommens, J. A. Buchanan, D. Markiewicz, T. K. Cox, A. Chakravarti, M. Buchwald, L. C. Tsui, Science. 1989, 245: 1073-1080. DOI:10.1126/science.2570460

4. K. De Boeck, M. D. Amaral. Lancet Respir. Med. 2016, 4(8): 662-674. DOI:10.1016/S2213-2600(16)00023-0

5. J. Zielinski, L. C. Tsui. Annu. Rev. Genet. 1995, 29: 777-807. DOI:10.1146/annurev.ge.29.120195.004021

6. K. De Boeck, M. Wilschanski, C. Castellani, C. Taylor, H. Cuppens, J. Dodge, M. Sinaasappel, Diagnostic Working Group, Thorax. 2006, 61: 627-635.

DOI:10.1136/thx.2005.043539

7. HGMD professional 2019.3, http://www.hgmd.cf.ac.uk/ac/ index.php

8. D. H. Andersen. Am. J. Dis. Childhood. 1938, 56, 344-399. DOI:10.1001/archpedi.1938.01980140114013

9. R. S. Pettit, C. Fellner. P T. 2014, 39(7), 500-511. DOI:10.1038/nj7510-500a

10. K. De Boeck, N. Derichs, I. Fajae, H. R. de Jonge, I. Bronsveld, I. Sermet, F. Vermeulen, D. N. Sheppard, H. Cuppens, M. Hug, P. Melotti, P. G. Middleton, M. Wilschanski on behalf of the ECFS Diagnostic Working Group and EuroCareCF WP3 Group on CF diagnosis. J Cyst. Fibros. 2011, 10(Suppl 2), S53-S66. DOI:10.1016/S1569-1993(11)60009-X

11. C. Castellani, H. Cuppens, M. Macek Jr, J. J. Cassiman, E. Kerem, P. Durie, et al. J Cyst. Fibros. 2008, 7, 179-196.

12. Cystic Fibrosis Mutation Database. Available at http:// www. genet.sickkids.on.ca 
13. The Clinical and Functional Translation of CFTR (CFTR2); Available at http://cftr2.org

14. M. D. Amaral, P. Pacheco, S. Beck, et al. J Med. Genet. 2001, $38,777-782$.

15. S. Beck, D. Penque, D. Garcia, A. Gomes, C. Farinha, L. Mata, S. Gulbenkian, K. Gil-Ferreira, A. Duarte, P. Pacheco, C. Barreto, B. Lopes, J. Cavaco, J. Lavinha, M. D. Amaral. Human mutation 1999, 14, 133-144.

DOI:10.1002/(SICI)1098-1004(1999)14:2<133::AID-HUMU5 $>3.0 . \mathrm{CO} ; 2-\mathrm{T}$

16. E. Kanavakis, M. Tzetis, T. Antoniadi, J. Trager-Synodinos, C. Kattamis, S. Doudounakis, G. Adam. J Med. Genet. 1995, 32, 406-407. DOI:10.1136/jmg.32.5.406

17. P. R. Sosnay, K. R. Siklosi, F. Van Goor, K. Kaniecki, H. Yu, N. Sharma, A. S. Ramalho, M. D. Amaral, R. Dorfman, J. Zielenski, D. L. Masica, R. Karchin, L. Millen, P. J. Thomas, G. P. Patrinos, M. Corey, M. H. Lewis, J. M. Rommens, C. Castellani, C. M. Penland, G. R. Cutting. Nat. Genet. 2013, 45, 1160-1167. DOI:10.1038/ng.2745

18. E. Dequeker, M. Stuhrmann, M. A. Morris, T. Casals, C. Castellani, M. Claustres, H. Cuppens, M. des Georges, C. Ferec, M. Macek, P. F. Pignatti, H. Scheffer, M. Schwartz, M. Witt, M. Schwarz, E. Girodon. Eur J Hum. Genet. 2009, 17, 51-65. DOI:10.1038/ejhg.2008.136

19. A. R. Smyth, S. C. Bell, S. Bojcin, M. Bryon, A. Duff, P. Flume, N. Kashirskaya, A. Munck, F. Ratjen, S. J. Schwarzenberg, I. Sermet-Gaudelus, K. W. Southern, G. Taccetti, G. Ullrich, S. Wolfe. J Cyst. Fibros. 2014, 13 (Suppl 1), S23-S42.

DOI:10.1016/j.jcf.2014.03.010
20. D. Feldman, R. Couderc, M. P. Audrezet, C. Ferec, T. Bienvenu, M. Desgeorges, M. Clusters, H. Mittre, M. Blayau, D. Bozon, et al. Hum. Mutat. 2003, 22, 340.

DOI:10.1002/humu.9183

21. K. Storm, E. Moens, L. Vits, H. De Vlieger, G. Delaere, M. D’Hollander, W. Wuyts, M. Biervliet, L. Van Schil, K. Desager, M. M. Nothen. J Cyst. Fibros. 2007, 6, 371-375.

DOI:10.1016/j.jcf.2006.10.013

22. H. Jung, C. S. Ki, W. J. Koh, K. M. Aho, S. I. Lee, J. H. Kim, J. S. Ko, J. K. Seo, S. L. Cha, E. S. Lee, J. W. Kim. KJLM. 2011, 31, 21924. DOI:10.3343/kjlm.2011.31.3.219

23. P. Fanen, N. Ghanem, M. Vidaud, C. Besmond, J. Martin, B. Costes, F. Plassa, M. Goossens. Genomics. 1992, 13, 770-776. DOI:10.1016/0888-7543(92)90152-I

24. K. H. Lim, L. Ferraris, M. E. Filloux, B. J. Raphael, W. G. Fairbrother. Proc. Natl. Acad. Sci. USA. 2011, 108, 11093-11098. DOI:10.1073/pnas.1101135108

25. B. C. Trapnell, C. S. Chu, P. K. Paakko, et al. Proc. Natl. Acad. Sci. USA. 1991, 88, 6565-6569.

26. N. L. White, C. F. Higgins, A. E. Trezise. Hum. Mol. Genet. 1998, 7, 363-369.

27. A. Hinzpeter, A. Aissat, E. Sondo, C. Costa, N. Arous, C. Gameiro, N. Martin, A. Tarze, L. Weiss, A de Becdelievre, et al. PLoS Genet. 2010; 6. pii: e1001153.

DOI:10.1371/journal.pgen.1001153

28. X. Liu, Q. Jiang, S. G. Mansfield, M. Puttaraju, Y. Zhang, W. Zhou, J. A. Cohn, M. A. Garcia-Blanco, L. G. Mitchell, J. F. Engelhardt. Nat. Biotechnol. 2002, 20, 47-52.

DOI:10.1038/nbt0102-47

\section{Povzetek}

Na svetu ima več kot 70.000 bolnikov cistično fibrozo (CF). Znane so številne variante v genu CFTR, vendar klinični pomen vseh še ni jasen. Trenutno je v Registru bolnikov Evropskega združenja za cistično fibrozo (ECFS Register) 195 bolnikov $\mathrm{z}$ varianto c.3140-26A $>\mathrm{G}$ (tradicionalna oznaka 3272-26A $>\mathrm{G}$ ), med njimi so samo 4 homozigoti. V prispevku predstavljamo 12 letne longitudinalne podatke enega izmed njih in sicer bolnice, ki se vodi v Centru za CF na Pediatrični kliniki, UKC Ljubljana, in njihovo primerjavo s podatki bolnikov s to varianto iz ECFS Registra in baze podatkov CFTR2. Vpliv spremembe, opredeljene pri tej bolnici, smo ocenili tudi na nivoju RNA v celicah nosnega epitela. Varianta povzroči spremenjeno izrezovanje intronov, kar vodi v premik bralnega okvirja in uvedbo prezgodnjega terminacijskega kodona. Pri tem normalen prepis pri bolnici ni bil prisoten. Vzrok za blago klinično sliko CF pri bolnikih homozigotnih za opisano varianto bi lahko bilo alternativno izrezovanje intronov v drugih tkivih.

Except when otherwise noted, articles in this journal are published under the terms and conditions of the Creative Commons Attribution 4.0 International License 